Vol 13, Issue 1, 2020

\title{
IN VITRO EVALUATION OF ANTIOXIDANT POTENTIAL AND TOTAL PHENOLIC CONTENT OF BARLERIA LONGIFLORA LEAF EXTRACTS
}

\begin{abstract}
JOTHIMUNIYANDI $\mathbf{M}^{1,2}$, JAYACHITRA $A^{3 *}$
${ }^{1}$ Research and Development Centre, Bharathiyar University, Coimbatore, Tamil Nadu, India. ${ }^{2}$ Department of Biochemistry, Meenakshi College of Allied Health Sciences, Meenakshi Mission Hospital and Research Centre, Madurai, Tamil Nadu, India. ${ }^{3}$ Department of Plant Biotechnology, School of Biotechnology, Madurai Kamaraj University, Madurai, Tamil Nadu, India. Email: joyan05@rediffmail.com
\end{abstract}

Received: 25 August 2019, Revised and Accepted: 02 December 2019

ABSTRACT

Objective: The aim of this present study is to estimate the antioxidant potential found in the leaves of Barleria longiflora that belongs to the family Acanthacea.

Methods: Antioxidant activity of six different solvent extracts system of B. longiflora leaves was assayed for 1,1-diphenyl-2-picrylhydrazyl (DPPH) free radical activity, scavenging of hydrogen peroxide $\left(\mathrm{H}_{2} \mathrm{O}_{2}\right)$, ferric reducing antioxidant activity, metal chelating ability assay, and total reducing ability. Total phenolic content of the extracts was determined by Folin-Ciocalteu method.

Results: The radical scavenging activity was evaluated by DPPH of ethanol extract at concentration of $100 \mu \mathrm{g} / \mathrm{mg}$ was found to be $56.5 \%$ followed by methanol $48.4 \%$, whereas maximum scavenging of $\mathrm{H}_{2} \mathrm{O}_{2}$ was observed in ethanol $83.4 \%$ followed by chloroform $70.8 \%$. Ethanolic extract of B. longiflora leaves showed the highest value in ferric reducing antioxidant power assay $74.8 \%$, metal chelating activity $61.6 \%$, and total reducing ability $0.76 \pm 0.02$ when compared to the standard ascorbic acid.

Conclusion: The results suggest that the antioxidant potential of the ethanol extract has the highest activity in compared to other five extracts of B. longiflora leaves.

Keywords: Barleria longiflora, Different solvents, Antioxidant activity, In vitro study.

(C) 2020 The Authors. Published by Innovare Academic Sciences Pvt Ltd. This is an open access article under the CC BY license (http://creativecommons. org/licenses/by/4. 0/) DOI: http://dx.doi.org/10.22159/ajpcr.2020.v13i1.35468

\section{INTRODUCTION}

All living organisms have complex systems of antioxidant enzymes. Reactive oxygen species (ROS) are generated in all living organisms during metabolism. It is produced in the form of superoxide anion, nitric oxide, hydroxyl radical, and hydrogen peroxide $\left(\mathrm{H}_{2} \mathrm{O}_{2}\right)$. Excessive formation of ROS may be harmful because they can initiate bimolecular oxidants which leads to cell injury, death, and create oxidative stress which results in numerous diseases and disorders such as cancer, diabetic, stroke, myocardial infection, Alzheimer's, and Parkinson's diseases. The negative effects of oxidative stress may be decreased by antioxidants [1].

Nowadays, available synthetic antioxidants such as butylated hydroxyl anisole, butylated hydroxyl toluene, and tertiary butylated hydroquinone have been suspected to cause or rapid negative health effects [2,3]. Moreover, these synthetic antioxidants also show less solubility and moderate activity. Therefore, there is an increasing interest in to identify the antioxidant compounds from natural resources. Plants have several active biomolecules [4], it can be an alternative to the use of synthetic compounds in food and pharmaceutical technology.

Several medicinal plants have been used as a nutritional adjunct and in the treatment of numerous diseases without proper knowledge of their functions. Although phytotherapy continues to be used in numerous countries, few plants have received scientific or medical scrutiny. Hence, the aim of this present research work is to find out the bioproductive effect of Barleria longiflora leaves by the antioxidant potential and total phenolic content. We have also done the phytochemical screening of $B$. longiflora to identify the number of secondary metabolites in six different solvent systems [5].

\section{METHODS}

\section{Collection of plant}

B. Longiflora, belongs to the family Acanthacea, was collected from Western Ghats, Madurai, Tamil Nadu, India. The specimen was identified by Taxonomist Rev. Fr. Dr. John Britto, Rapinart Herbarium, St. Joseph's College, Tiruchirappalli, Tamil Nadu. The plant leaves were washed in running tap water before being shade dried at room temperature.

\section{Preparation of extracts}

Dried leaves were crushed in electric grinder and powdered. About $50 \mathrm{~g}$ of leaves powder was packed into Soxhlet apparatus and extracted consecutively with petroleum ether (60-80\%), chloroform, ethyl acetate, ethanol, methanol, and distilled water. Each extract was airdried thoroughly in rotary evaporator and stored in $4^{\circ} \mathrm{C}$ for further investigation.

\section{Antioxidant activities}

1,1-Diphenyl-2-picrylhydrazyl (DPPH) free radical scavenging activity

The free radical activity of leaf extracts was measured by DPPH according to the Blois method [6].

DPPH percentage inhibition $(\%)=$ Abs $($ Control $)-$ Abs $($ Sample $) /$ Abs (Control) $\times 100$

Scavenging of $\mathrm{H}_{2} \mathrm{O}_{2}$

The scavenging ability of the leaf extracts to $\mathrm{H}_{2} \mathrm{O}_{2}$ was determined according to the method of Ruch et al. [7] and Gulcin et al. [8].

The percentage of scavenging of $\mathrm{H}_{2} \mathrm{O}_{2}$ was calculated as = Abs (Control) - Abs (Sample)/Abs (Control) $\times 100$ 


\section{Total reducing ability}

Total reducing capacity of leaf extracts was determined to the method of Oyaizu [9]. Ascorbic acid (20-100 $\mu \mathrm{g} / \mathrm{ml})$ was used as a positive control. The maximum absorbance of the reaction mixture the greater is the reducing power.

Total reducing capacity $(\%)=$ Abs $($ Control $)-$ Abs $($ Sample $) /$ Abs (Control) $\times 100$

\section{Metal chelating ability}

The ferrous ion-chelating ability of leaf extracts was evaluated by Decker and Welch [10] method. The ferrous ion inhibition of percentage was calculated using the formula:

Metal chelating ability $(\%)=$ Abs $($ Control) - Abs $($ Sample $) /$ Abs (Control) $\times 100$

\section{Ferric reducing antioxidant power (FRAP) assay}

The FRAP assays were performed by Benzie and Strain [11] method. The results are expressed as ascorbic acid equivalent antioxidant capacity.

FRAP $(\%)=$ Abs $($ Control $)-$ Abs (Sample) $/$ Abs (Control) $\times 100$

\section{Determination of total phenolic}

The amount of total phenolics in the extracts was determined by the Folin-Ciocalteu method Singleton and Rossi [12]. Samples from the extracts were evaluated at a final concentration of $0.1 \mathrm{mg} / \mathrm{ml}$. The total phenolic content was expressed as $\mathrm{mg} / \mathrm{g}$ Gallic acid equivalent.

\section{Statistical analysis}

All of the experiments were conducted in triplicate $(n=3)$ and one-way ANOVA (using SPSS 11.5 statistical software) was used to compare the mean values of every treatment. Significant differences between the means of parameters were determined using the Duncan test $(\mathrm{p}<0.05)$.

\section{RESULTS AND DISCUSSION}

Plants and plant-derived compounds have been well known to play a dominant role in health care of humans and more than $50 \%$ of the

Table 1: DPPH free radical scavenging activity of six different extracts of Barleria longiflora leaves

\begin{tabular}{lll}
\hline S. No. & Extracts $(\mathbf{1 0 0} \boldsymbol{\mu l})$ & Percentage of inhibition \\
\hline 1. & Standard $(\mathrm{BHT})$ & $63.9 \pm 0.012$ \\
2. & Petroleum ether & $13.3 \pm 0.029$ \\
3. & Chloroform & $46.9 \pm 0.050$ \\
4. & Ethyl acetate & $36.1 \pm 0.066$ \\
5. & Ethanol & $56.5 \pm 0.027$ \\
6. & Methanol & $48.4 \pm 0.054$ \\
7. & Aqueous & $34.3 \pm 0.064$ \\
\hline
\end{tabular}

Values are given in mean \pm SD, means were significantly different when $\mathrm{p}<0.05$; DPPH: 1,1-Diphenyl-2-picrylhydrazyl. BHT: Butylated hydroxyl toluene, SD: Standard deviation entire modern drugs in clinical use are of natural product origin [13]. Hence, plant-based drugs are being increasingly preferred in modern medicine. Natural compounds are derived from nutritional sources; provide a large number of antioxidants. They are acted as a protective shield for our body against certain unfortunate diseases such as arterial, cancer, and cardiac-related diseases. The current researches on free radicals have promised a revolutionary enhancement in health and lifestyle of human beings [14].

\section{Antioxidant activities}

There are different methods to determine the antioxidant capacity of folk medicinal plants. In this present study, antioxidant activities of B. longiflora were estimated using five different assays such as DPPH free radical scavenging activity, scavenging of $\mathrm{H}_{2} \mathrm{O}_{2}$, total reducing ability, ferric reducing antioxidant activity, and metal chelating ability assay. These five represented different mechanisms of antioxidant action. All the five assays were standardized by five different concentrations depends on the method. Six different leaf extracts of $B$. longiflora were compared with the highest concentration of standard. The antioxidant activities of plant species differ from depends on the methodology and their mechanism [15].

\section{DPPH free radical scavenging activity}

The result of antioxidants on DPPH radical scavenging is thought to be to hydrogen donating ability. DPPH is a stable free radical and it accepts an electron or hydrogen radical to become a stable diamagnetic particle. When a DPPH solution is mixed with a substrate acting as a hydrogen atom donor, a stable non-radical form of DPPH is obtained with simultaneous change of the violet color to pale yellow [16]. Hence, DPPH has been used extensively as a free radical to evaluate the reducing substance and is a useful reagent for investigating the free radical scavenging activities of molecules [17]. In this present study, the highest percentage of radical scavenging activity was observed in ethanol leaves extraction of $B$. longiflora (56.5 \pm 0.027$)$; Kalpana et al. noticed maximum percentage DPPH radical scavenging activity in ethanol extract of B. longiflora [18].

\section{Scavenging of $\mathrm{H}_{2} \mathbf{O}_{2}$}

$\mathrm{H}_{2} \mathrm{O}_{2}$ can able to inactivate some enzymes directly, usually by oxidation of essential thiol (-SH) groups. $\mathrm{H}_{2} \mathrm{O}_{2}$ when enter into the cells, it can possible to react with $\mathrm{Fe}^{2+}$ and possibly $\mathrm{Cu}^{2+}$ to form hydroxyl radicals and this may be a source of many of its toxic effects [19]. It is consequently compensation for cells to control the amount of $\mathrm{H}_{2} \mathrm{O}_{2}$ that is allowed to accumulate [20]. In this present study, the highest anti- $\mathrm{H}_{2} \mathrm{O}_{2}$ activity was observed in ethanol extract of $B$. longiflora $(83.4 \pm 0.18)$. Methanol extract of Barleria noctiflora L. root has scavenging activity in high when compared to the leaf [21]. Mohan and Ruba reported that among the five solvents, methanol extract has highly acted to remove the hydroxyl radicals from the sugar and inhibit the reaction when compare with standard [22].

\section{Metal chelating ability}

Ferrozine can chelate with $\mathrm{Fe}^{2+}$ by quantitatively and this reaction is restricted in the presence of other chelating agents and results in reduce of the red color of the ferrozine-Fe ${ }^{2+}$ complex. Measurement of

Table 2: Antioxidant activities different solvent systems of Barleria longiflora leaf extracts

\begin{tabular}{|c|c|c|c|c|c|}
\hline S. No. & Different extracts & $\begin{array}{l}\text { Scavenging of hydrogen peroxide } \\
(\%)\end{array}$ & $\begin{array}{l}\text { FRAP assay } \\
(\%)\end{array}$ & $\begin{array}{l}\text { Metal chelating ability } \\
(\%)\end{array}$ & $\begin{array}{l}\text { Total reducing ability } \\
(\mu \mathrm{g} / \mathrm{ml})\end{array}$ \\
\hline 1. & Standard (Ascorbic acid) & $61.9 \pm 0.56$ & $83.3 \pm 0.02$ & $69.6 \pm 0.03$ & $0.70 \pm 0.01$ \\
\hline 2. & Petroleum ether & $12.3 \pm 0.01$ & $57.5 \pm 0.05$ & $6.1 \pm 0.06$ & $0.02 \pm 0.0$ \\
\hline 3. & Chloroform & $70.8 \pm 0.07$ & $15.2 \pm 0.07$ & $10.2 \pm 0.07$ & $0.03 \pm 0.0$ \\
\hline 4. & Ethyl acetate & $41.1 \pm 0.06$ & $66.8 \pm 0.10$ & $20.7 \pm 0.08$ & $0.13 \pm 0.03$ \\
\hline 5. & Ethanol & $83.4 \pm 0.18$ & $74.8 \pm 0.08$ & $61.6 \pm 0.03$ & $0.76 \pm 0.02$ \\
\hline 6. & Methanol & $34.3 \pm 0.10$ & $59.5 \pm 0.03$ & $57.9 \pm 0.06$ & $0.42 \pm 0.03$ \\
\hline
\end{tabular}


Table 3: Total phenolic content of Barleria longiflora leaf extracts

\begin{tabular}{lll}
\hline S. No. & Extracts $(\mathbf{1 0 0} \boldsymbol{\mu l})$ & TPC $(\mathbf{m g} / \mathbf{g})$ \\
\hline 1. & Standard (Gallic acid) & $1.07 \pm 0.08$ \\
2. & Petroleum ether & $0.05 \pm 0.01$ \\
3. & Chloroform & $0.09 \pm 0.01$ \\
4. & Ethyl acetate & $0.18 \pm 0.06$ \\
5. & Ethanol & $1.09 \pm 0.09$ \\
6. & Methanol & $0.80 \pm 0.08$ \\
7. & Aqueous & $0.68 \pm 0.03$ \\
\hline
\end{tabular}

Values are given in mean \pm SD, Means were significantly different when $p<0.05$; TPC: Total phenolic content. SD: Standard deviation

the color reduction determines the chelating activity to compete with ferrozine for the ferrous ions [23]. The result is indicating that the ethanolic extract $(61.6 \pm 0.03)$ has more activity when compound to other solvent systems of $B$. longiflora. The antioxidants present in plant extracts forms a coordinate complex with the metal ions (chelating activity) and block the transfer of electrons. Thus, oxidation reaction is arrested and free radicals are not produced. Sujatha and Sekar reported that maximum chelation was showed in methanolic extract of Litsea laevigata leaves when compared with other solvent systems of leaf and stem [24].

\section{FRAP assay}

In the FRAP assay, antioxidants in the compounds reduce ferric (III) to ferrous (II) in a redox-linked colorimetric reaction [25] that involves single electron transfer. The reducing power indicates that the antioxidant compounds are electron donors and reduce the oxidized intermediate of the lipid peroxidation process so that they can act as primary and secondary antioxidants Yen and Chen [26]. In the present study, higher reducing power $(74.8 \pm 0.08)$ was observed in ethanol extract of $B$. longiflora. Ranade et al. reported ethanolic extract 1.5 times higher than acetone and aqueous stem extracts of Barleria prionitis [27].

\section{Total reducing ability}

The total antioxidant activity of $B$. longiflora leaves was evaluated, it indicates that they are electron donors and can decrease the oxidized intermediates of lipid peroxidation process. Hence samples can act as antioxidants [28]. The results showed significant value in ethanolic extract $(0.76 \pm 0.02)$ compared to other five leaf extracts of $B$. longiflora. Ethanolic extract exhibited potent power activity compared to that aqueous extract of $B$. prionitis [29].

\section{Determination of total phenolic}

Phenolic compounds are secondary metabolites that play a key role in maintenance of the human body. Phenolics are compounds found in plants and have been reported to have numerous biological activities including antioxidant properties. Many studies are focused on the biological activities of phenolic compounds; they are potential antioxidants and free radical scavengers. In this present study, ethanolic leaves extract of $B$. longiflora showed higher phenolic contents compared to other extracts tested. Polyphenolic content was high in ethanolic extract compared to aqueous extract of B. prionitis [30].

\section{CONCLUSION}

The present study for the $1^{\text {st }}$ time reports the antioxidant activities of five different methods on six different solvents of $B$. longiflora leaves. Maximum absorbance of the reaction mixture indicates higher reduction potential. The reducing capacity of an extract may provide as a significant indicator of its potential antioxidant activity [30]. Hence, the ethanolic leaf extracts of $B$. longiflora can be a potential source of antioxidant activity. Further, to identify the bioactive compounds present in the leaves of $B$. longiflora and analyze their biological activities.

\section{AUTHORS' CONTRIBUTIONS}

Both authors have contributed equally.

\section{CONFLICTS OF INTEREST}

The authors declare that they have no conflicts of interest.

\section{REFERENCES}

1. Chew YL, Lim YY, Omar M, Khoo KS. Antioxidant activity of three edible seaweeds from two areas in South East Asia. LWT-Food Sci Technol 2008;41:1067-72

2. Kumar KS, Ganesan K, Rao PV. Antioxidant potential of solvent extracts of Kappaphycus alvarezii (Doty) doty an edible seaweed. Food Chem 2008;107:289-95.

3. Pourmorad F, Hosseinimehr SJ, Shahabimajd N. Antioxidant activity, phenol and flavonoid contents of some selected Iranian medicinal plants. Afr J Biotechnol 2006;5:1142-45.

4. Umesh TG. In vitro antioxidant potential, free radical scavening and cytotoxic activity of Simarouba glauca leaves. Int J Pharm Pharm Sci 2015;7:411-6

5. Muniyandi MJ, Jayachitra A. Phytochemical investigation of Barleria longoflora Linn. F. In Western Ghats Madurai. Res J Life Sci Bioinform Pharm Chem Sci 2019;5:700-9.

6. Blois MS. Antioxidant determinations by the use of a stable free radical. Nature 1958;181:1199-200.

7. Ruch RJ, Cheng SJ, Klaunig JE. Prevention of cytotoxicity and inhibition of intracellular communication by antioxidant catechins isolated from Chinese green tea. Carcinogen 1989;10:1003-8.

8. Gulcin I, Oktay M, Kireçci E, Kufreviolu O. Screening of antioxidant and antimicrobial activities of anise (Pimpinella anisum L.) seed extracts. Food Chem 2003;83:371-82.

9. Oyaizu M. Studies on products of browning reactions: Antioxidant activities of product of browning reaction prepared from glucosamine. Jpn J Nutr 1986;44:307-15

10. Decker EA, Welch B. Role of ferritin as a lipid oxidation catalyst in muscle food. J Agric Food Chem 1990;38:674-7.

11. Benzie IF, Strain JJ. Ferric reducing ability of plasma (FRAP) as a measure of antioxidant power: The FRAP assay. Anal Biochem 1996;239:70-6.

12. Singleton VL, Rossi JA. Colorimetry of total phenolics with phosphomolybdic-phosphotungstic acid reagents. Am J Enol Vitic 1965;16:144-58.

13. Rosangkima G, Prasad SB. Antitumour activity of some plants from Meghalaya and Mizoram against murine ascites Dalton's lymphoma. Indian J Exp Biol 2004;42:981-8.

14. Devasagyam TP, Tilak JC, Boloor KK, Sane KS, Ghaskadbi SS, Lele RD. Free radicals and antioxidants in human health: Current status and future prospects. J Assoc Physicians India 2004;52:794-804.

15. Archana D, Dixitha M, Santhy KS. Antioxidant and anticlastogenic potential of Piper longum L. Int J App Pharm 2015;7:11-4.

16. Molyneux $P$. The use of the stable free radical diphenylpicrylhydrazyl (DPPH) for the antioxidant activity. Songklanakarin J Sci Technol 2004;26:211-9.

17. Duan XJ, Zhang WW, Li XM, Wang BG. Evaluation of antioxidant property of extract and fractions obtained from a red alga, Polysiphonia urceolata. Food chem 2006;95:37-43.

18. Kalpana S, Vijai D, Premalatha S. Antioxidant activity of different solvent extracts of Barleria longiflora Linn. Int J Curr Res Biol Med 2016;1:1-8.

19. Halliwell B. Reactive oxygen species in living systems: Source, biochemistry and role in human disease. Am J Med 1991;91:14-22.

20. Devi KP, Suganthy N, Kesika P, Pandian SK. Bioprotective properties of seaweeds: In vitro evaluation of antioxidant activity and antimicrobial activity against food borne bacteria in relation to polyphenolic content. BMC Complement Altern Med 2008;8:1-11.

21. Yadav SA, Raj AJ, Sathishkumar R. In vitro antioxidant activity of Barleria noctiflora L. f. Asain Pac J Trop Biomed 2012;S716-22.

22. Mohan VR, Ruba AA. In vitro antioxidant potential of whole plant of Andrographis echiodies [L] nees (Acanthaceae). Int J Pharm Pharm Sci 2016;8:70-5.

23. Soler-Rivas C, Espin JC, Wichers HJ. An easy and fast test to compare total free radical scavenger capacity of foodstuffs. Phytochem Anal 2000;11:330-8.

24. Sujatha S, Sekar T. Free radical scavening activity leaf extract of Litsea laevigata gamble. Int J Pharm Pharm Sci 2019;11:96-103. 
25. Li YF, Guo C, Yang J, Wei J, Xu J, Cheng S. Evaluation of antioxidant properties of pomegranate peel extract in comparison with pomegranate pulp extract. Food Chem 2006;96:254-60.

26. Yen GH, Chen HY. Antioxidant activity of vatious tea extract in relation to their antimutagenicity. J Agric Food Chem 1995;43:27-32.

27. Ranade R, Jain A, Joshi N. Estimation of phenolic compunds by RPHPLC and antioxidant activity in leaf and stem extracts of Barleria prionitis L. Int J Pharm Sci Res 2016;7:2445-57.
28. Chanda S, Dave R. In vitro models for antioxidant activity evaluation and some medicianal plants possessing antioxidant properties: An overview. Afr J Microbiol Res 2009;3:981-96.

29. Cheta C, Suraj M, Maheswari C, Rahul A, Priyanka P. Screening of antioxidant activity and phenolic content of whole plant of Barleria prionitis Linn. Int J Res Ayurveda Pharm 2011;2:1313-9.

30. Jayanthi P, Lalitha P. Reducing power of the solvent extarcts of Eichhornia crassipes [MART] solms. Int J Pharm Sci 2011;3:126-8. 